\title{
DEVELOPMENT OF A STORM EROSION CLIMATOLOGY FOR THE NEW JERSEY COAST, US
}

\author{
Laura Lemke ${ }^{1}$ and Jon K. Miller ${ }^{2}$
}

\begin{abstract}
In this study, the Storm Erosion Index (SEI), developed by Miller and Livermont (2008), is used to reevaluate storms that have impacted New Jersey over the past several decades based on their erosion potential. This index considers all three drivers of coastal erosion including wave height, water level, and storm duration and has been shown to more closely correlated to observed erosion than more traditional indices (Miller and Livermont 2008). Here, storms are assessed at thirteen shoreline segments defined along the Atlantic coast of New Jersey. When reevaluated with SEI, the top three storms across all shoreline segments are the December 1992 nor'easter, the Veteran's Day Storm in November 2009, and Hurricane Sandy in October 2012. In general, the December 1992 nor'easter and Hurricane Sandy are more highly ranked in the northern half of the state with Hurricane Sandy having a maximum return period of 38 years. The Veteran's Day Storm on the other hand is more highly ranked in the southern half of the state having a maximum return period of 42 years. A closer look at these three storms illustrates the importance of each of the three drivers of coastal erosion in determining erosion potential. A particular emphasis is placed on storm duration which explains why the Veteran's Day Storm ( $t_{d}=\sim 90$ hours) outranks Hurricane Sandy ( $t_{d}=\sim 60$ hours) in the southern portion of the state. The assessment performed in this study produces a record of historical storms ranked by SEI that future storms can be compared to. This allows for an understanding of the erosion potential of future storms in the context of what has occurred previously.
\end{abstract}

Keywords: coastal storm, beach erosion, storm intensity, New Jersey

\section{INTRODUCTION}

In the past several decades there have been a number of storms that have impacted the mid-Atlantic region of the United States and caused significant damage along its coast. To mitigate such damages, coastal communities require reliable information about an oncoming storm in order to anticipate its impacts and make preparatory decisions. With the beach and dune system being one of a community's defenses, beach erosion due to storms is a major concern. Thus, there exists a need to properly estimate a storm's severity in terms of erosion potential prior to its impact.

Traditionally, storm intensity has been quantified by one or more of the storm's properties. For tropical storms this includes metrological properties such as barometric pressure, maximum wind speed, or storm surge potential. The most well-known example of this in the United States is the SaffirSimpson Hurricane Wind Scale (SSHWS) which classifies hurricanes on a scale from 1 through 5 based on their one-minute maximum sustained wind speed (Schott et al. 2012). These categories are often used sometimes inappropriately to infer potential property damage and flooding due to storm surge. There have been several criticisms of this scale as it relies solely on wind speed and does not consider other parameters such as measured storm surge, waves, or precipitation (Kantha 2006). Two recent storms that have highlighted some of the shortcomings of the SSHWS are Tropical Storm Debby and Superstorm Sandy, both of which made landfall in 2012. Neither storm was classified as a hurricane according to the SSHWS at landfall, yet both caused extreme erosion and significant damage. (Wehof et al. 2014). Suggestions to modify the scale have included the addition of parameters such as storm size and forward speed (Done et al. 2015; Hebert et al. 2010).

Extratropical storms, also known as nor'easters, are fundamentally different from tropical storms in terms of how they form and draw their energy. Therefore, they cannot be categorized by wind speed the same way tropical storms typically are (Herrington and Miller 2010). Understanding the intensity of these types of storms is important however, particularly in the mid-Atlantic region, where they routinely cause significant beach erosion and property damage along the coast. Although these storms are often less intense than their tropical counterparts they impact this area of the coast more frequently, resulting in extreme cumulative damage. Traditionally, a stage frequency analysis of either water level or wave height has been used to estimate storm severity of extratropical storms. However, this approach, while suitable for some applications, such as predicting whether a road will flood, may not adequately

\footnotetext{
${ }^{1}$ Department of Civil, Environmental, and Ocean Engineering, Stevens Institute of Technology, 711 Hudson Street, Hoboken, New Jersey, 07030, USA

2 Department of Civil, Environmental, and Ocean Engineering, Stevens Institute of Technology, 711 Hudson Street, Hoboken, New Jersey, 07030, USA
} 
estimate a storm's potential to cause erosion as a combination of parameters are involved in this process.

Beach erosion, which is one of the common impacts associated with both types of storms, is driven by three primary parameters, including wave conditions, total water level, and storm duration. The wave conditions relate to how much energy is available to generate sediment movement and to what direction that sediment will move. The total water level, which includes the tide level and storm surge, determines how high on the beach the water rises and thereby how much of the beach is subject to wave action. Storm duration describes how long the beach is subjected to intensified wave conditions and elevated water levels. The storm duration is therefore associated with how much erosion is accumulated over the length of the storm.

The Veteran's Day Storm which impacted New Jersey in November 2009 demonstrates how stage frequency analysis of water levels may not adequately indicate severity in terms of erosion. This storm, resulted in severe beach erosion despite barely exceeding the moderate flooding threshold set by the National Weather Service, and is considered one of the most damaging storms in New Jersey in recent history (Herrington and Miller 2010). This can be attributed to the extremely large waves generated by the storm and the fact that the storm persisted over several tidal cycles. Storms such as the Veterans Day Storm, and Tropical Storm Debby and Hurricane Sandy described above, emphasize the difficulty of assessing a storm based on a single parameter.

Several more robust indices have been developed which take multiple parameters into account. These include: Dolan and Davis (1992) who derived an index specifically for extratropical storms based on maximum wave energy and duration; Mendoza et al. (2011) who modified this scale; and Kriebel et al. (1996) who developed an index for extratropical storms which considered wave height, storm surge, and storm duration. More recently, Miller and Livermont (2008) developed the Storm Erosion Index (SEI) which evaluates storms based on their erosion potential considering all three drivers of coastal erosion: wave height; water level; and storm duration. Unlike many other indices, this index makes no distinction between tropical and extratropical storms. It has been successfully applied to a number of locations including but not limited to the Gulf of Mexico and Atlantic coasts of Florida, North and South Carolina, and New Jersey and has been shown to be more closely correlated to observed erosion than more traditional indices (Miller 2015; Miller and Livermont 2008; Miller and Wehof 2013; Wehof et al. 2014).

The purpose of the research presented here is to reevaluate storms that have impacted New Jersey over the past few decades based on their erosion potential. This assessment produces a record of historical storms that future storms can be compared to, and thereby allows for an understanding of the erosion potential of future storms in the context of what has occurred previously. To assess the erosion potential of the historical storms, the Storm Erosion Index (SEI), developed by Miller and Livermont (2008) is applied. SEI is chosen as it considers all three drivers of beach erosion (wave height, water level, and storm duration) for both tropical and extratropical storms, each of which impact the New Jersey coast. The following sections will describe the Storm Erosion Index and how it is applied in this research in more detail.

\section{METHODS}

\section{Storm Erosion Index}

The Storm Erosion Index's (SEI) foundation is in the known physical response of a beach profile due to increased water levels. The simplest form of this response is the well-known Bruun Rule (Bruun 1962). SEI is based on a form of this rule modified by Dean and Dalrymple (2002) to predict the equilibrium shoreline recession $(\Delta y)$, due to an increase in water level $\mathrm{S}$, and cross-shore varying wave setup, $\eta$, due to breaking waves (Figure 1):

$$
\Delta y=-W_{*}\left[\frac{0.068 H_{b}+S}{B+1.28 H_{b}}\right]
$$

In Equation $1 \mathrm{H}_{\mathrm{b}}$ is the breaking wave height $\left(\mathrm{H}_{\mathrm{b}}=0.8 \mathrm{~h}_{\mathrm{b}}\right), W_{*}$ is the width of the active surfzone, and

$\mathrm{B}$ is the berm height. $W_{*}$ is approximated as the distance to the breakpoint assuming an equilibrium beach profile and is determined via: 


$$
W_{*}=\left(A h_{b}\right)^{3 / 2}
$$

where $\mathrm{h}_{\mathrm{b}}$ is the water depth at the breakpoint and $\mathrm{A}$ is the sediment scale parameter which is related to a median grain size (Dean et al. 2001; Moore 1982).

Miller and Dean (2004) utilized a time-varying form of this modified Bruun Rule to predict equilibrium shoreline change based on wave height, water level, and storm duration. The time-varying form was adapted by Miller and Livermont (2008) and was used to represent an Instantaneous Erosion Intensity (IEI):

$$
I E I\left(t_{i}\right)=W_{*}\left(t_{i}\right)\left[\frac{0.068 H_{b}\left(t_{i}\right)+S\left(t_{i}\right)}{B+1.28 H_{b}\left(t_{i}\right)}\right]
$$

where $t_{i}$ is a time index and the negative sign is dropped for convenience. IEI is representative of the intensity of a storm at a given point in time based on its instantaneous breaking wave height and surge. In the time varying version, the surge is taken as the instantaneous water level with respect to mean sea level. Two parameters that are based on IEI and that can be used to characterize a storm intensity are the Peak Erosion Intensity (PEI) and the Storm Erosion Index (SEI). PEI is the maximum value of the IEI over the duration of the storm, $t_{d}$, and represents the erosive power at the peak of the storm. SEI is the sum of the IEI over $t_{d}$, and represents the cumulative erosion potential:

$$
S E I=\sum_{t_{d}} I E I\left(t_{i}\right)=\sum_{t_{d}}\left\{W_{*}\left(t_{i}\right)\left[\frac{0.068 H_{b}\left(t_{i}\right)+S\left(t_{i}\right)}{B+1.28 H_{b}\left(t_{i}\right)}\right]\right\}
$$

Further details regarding the application of the index are provided in the following section.

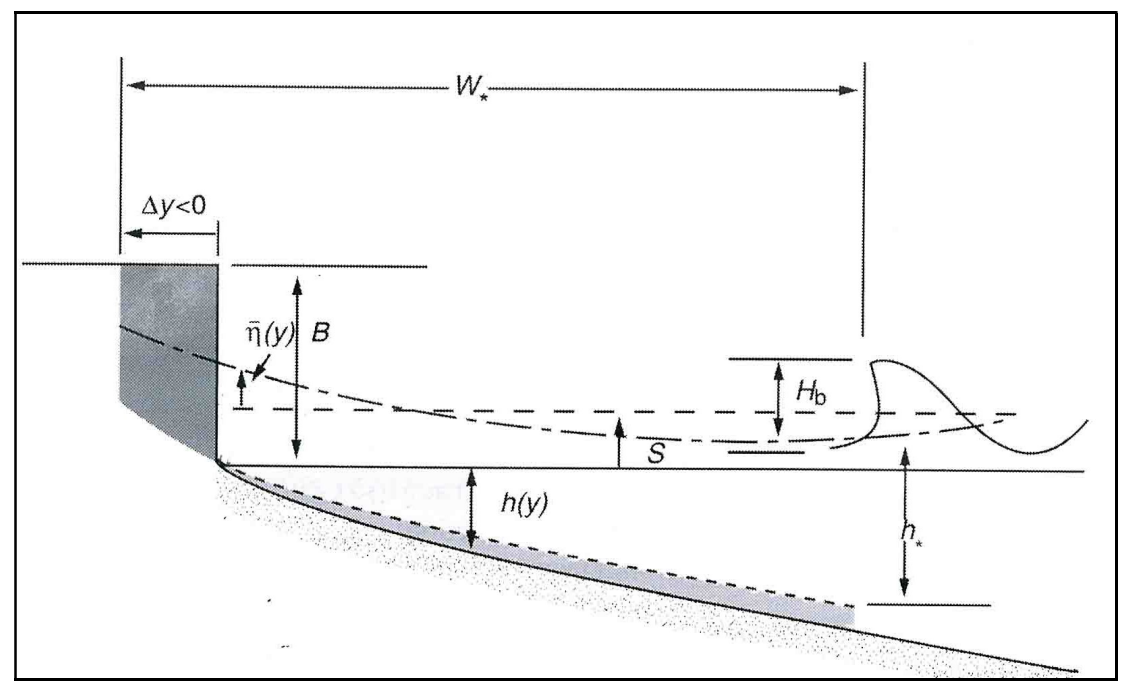

Figure 1. Definition of parameters used to derive Storm Erosion Index (SEI). Figure from Dean and Dalrymple (2002).

Although SEI estimates the potential for erosion based on storm parameters rather than actual storm impacts, Miller and Livermont (2008) found that storms with higher SEI values typically caused greater erosion. This was found by comparing SEI values for storms at Wildwood, New Jersey to qualitative post-storm erosion reports conducted by the New Jersey Department of Environmental Protection (NJDEP). Events where the erosion was described as moderate to severe typically had higher SEI values than those with erosion described as slight or minor.

Here, we classify storms by their SEI and PEI by two means. Firstly, an extreme value analysis (EVA) is performed to determine the return period associated with an individual storm based on its SEI and PEI. The Peak-Over-Threshold (POT) method is used where all exceedances above a specified 
threshold are assumed to be represented by a Generalized Pareto Distribution (GPD). Thresholds are selected with consideration of optimization techniques described in Palutikof et al. (1999) and Lang et al. (1999) as well as visual fit. The advantage of this method over other EVA methods such as the Annual Maximum Series (AMS) is that it allows for multiple large events during the same year to be captured rather than limiting the analysis to just one event per year. This is useful given the possibility to have multiple large storms during a single year.

Additionally, a simplified classification is made by applying a categorization procedure that mimics the Saffir-Simpson Hurricane Wind Scale. This procedure categorizes storms as 1 through 5 and may be useful for relaying storm severity to the public. This categorization is site specific and provides a general measure of erosion potential. In this procedure, the storm with the lowest SEI value at a given site is assigned a Category 1 and that with the highest is assigned Category 5. Linear interpolation is used to assign categories to the remaining storms in the site's record according to:

$$
C a t=5 \times\left[\frac{S E I-S E I_{\min }}{S E I_{\max }-S E I_{\min }}\right]
$$

where this value is rounded up to the nearest whole integer. The same categorization procedure is applied for PEI.

\section{New Jersey Climatology Development}

Data

As discussed, the purpose of this research is to produce a historical record of storms which have occurred over the last several decades in New Jersey and to classify them based on their erosion potential using the Storm Erosion Index. The aim is to create a storm erosion climatology which any future storms in the area could be compared to. As both storm conditions (wave conditions and water levels) and those pertaining to the beach (shoreline angle, sediment grain size, berm height) vary spatially, New Jersey is divided into thirteen smaller segments and a historical record is developed for each. These shoreline segments are depicted in Figure 2 and are tabulated in Table 1. Shoreline Segments 5 through 13 represent individual barrier islands whereas Shoreline Segments 1 through 4, which occur on the headland portion of the state, are defined by changes in shoreline orientation.

Information required for each shoreline segment pertaining to the beach properties are summarized in Table 1. Shoreline orientation is provided as the angle that is shore-normal, measured with respect to north. Berm height and sediment size are assumed to be constant over the period of the analysis. These values are obtained from information collected by Richard Stockton's Coastal Research Center. This group, twice a year, surveys profiles along the New Jersey coast. The average berm elevation for each shoreline segment is determined by averaging the berm heights of each of the profiles taken in Fall 2015 within each segment (Farrell et al. 2016). Similarly, the average median grain size is determined for each segment based on samples analyzed by Richard Stockton at each profile in 2011 (Flynn). Generally, sediment sizes are coarser in northern New Jersey and are finer in the southern portion of the state.

\begin{tabular}{|c|c|c|c|c|c|c|c|}
\hline ID & Northern Bound & Southern Bound & $\begin{array}{l}\text { Length } \\
(\mathrm{km})\end{array}$ & $\begin{array}{l}\text { Avg. d50 } \\
\text { (mm) }\end{array}$ & $\begin{array}{c}\text { Avg. Berm } \\
\text { Elev. } \\
\text { (m NAVD88) }\end{array}$ & $\begin{array}{l}\text { Shore- } \\
\text { normal } \\
\text { Angle }\end{array}$ & $\begin{array}{l}\text { Local } \\
\text { WIS } \\
\text { Station }\end{array}$ \\
\hline 1 & Sandy Hook & Sea Bright & 11.7 & 0.37 & 2.1 & 83 & 63126 \\
\hline 2 & Sea Bright & Long Branch & 7.2 & 0.47 & 2.2 & 95 & 63127 \\
\hline 3 & Long Branch & Shark River Inlet & 13.0 & 0.51 & 2.2 & 102 & 63128 \\
\hline 4 & Shark River Inlet & Manasquan Inlet & 9.5 & 0.57 & 2.5 & 102 & 63130 \\
\hline 5 & Manasquan Inlet & Barnegat Inlet & 37.0 & 0.52 & 2.6 & 100 & 63133 \\
\hline 6 & Barnegat Inlet & Little Egg Inlet & 33.6 & 0.42 & 2.3 & 120 & 63138 \\
\hline 7 & Little Egg Inlet & Absecon Inlet & 13.4 & 0.27 & 1.3 & 132 & 63140 \\
\hline 8 & Absecon Inlet & $\begin{array}{l}\text { Great Egg } \\
\text { Harbor Inlet }\end{array}$ & 12.9 & 0.31 & 1.6 & 145 & 63142 \\
\hline 9 & $\begin{array}{c}\text { Great Egg Harbor } \\
\text { Inlet }\end{array}$ & Corson Inlet & 12.6 & 0.26 & 1.5 & 130 & 63143 \\
\hline 10 & Corson Inlet & Townsends Inlet & 10.6 & 0.25 & 1.8 & 119 & 63145 \\
\hline 11 & Townsends Inlet & Hereford Inlet & 11.9 & 0.23 & 1.4 & 126 & 63147 \\
\hline 12 & Hereford Inlet & Cape May Inlet & 9.8 & 0.17 & 1.8 & 135 & 63149 \\
\hline 13 & Cape May Inlet & Delaware Bay & 7.9 & 0.88 & 2.3 & 163 & 63151 \\
\hline
\end{tabular}




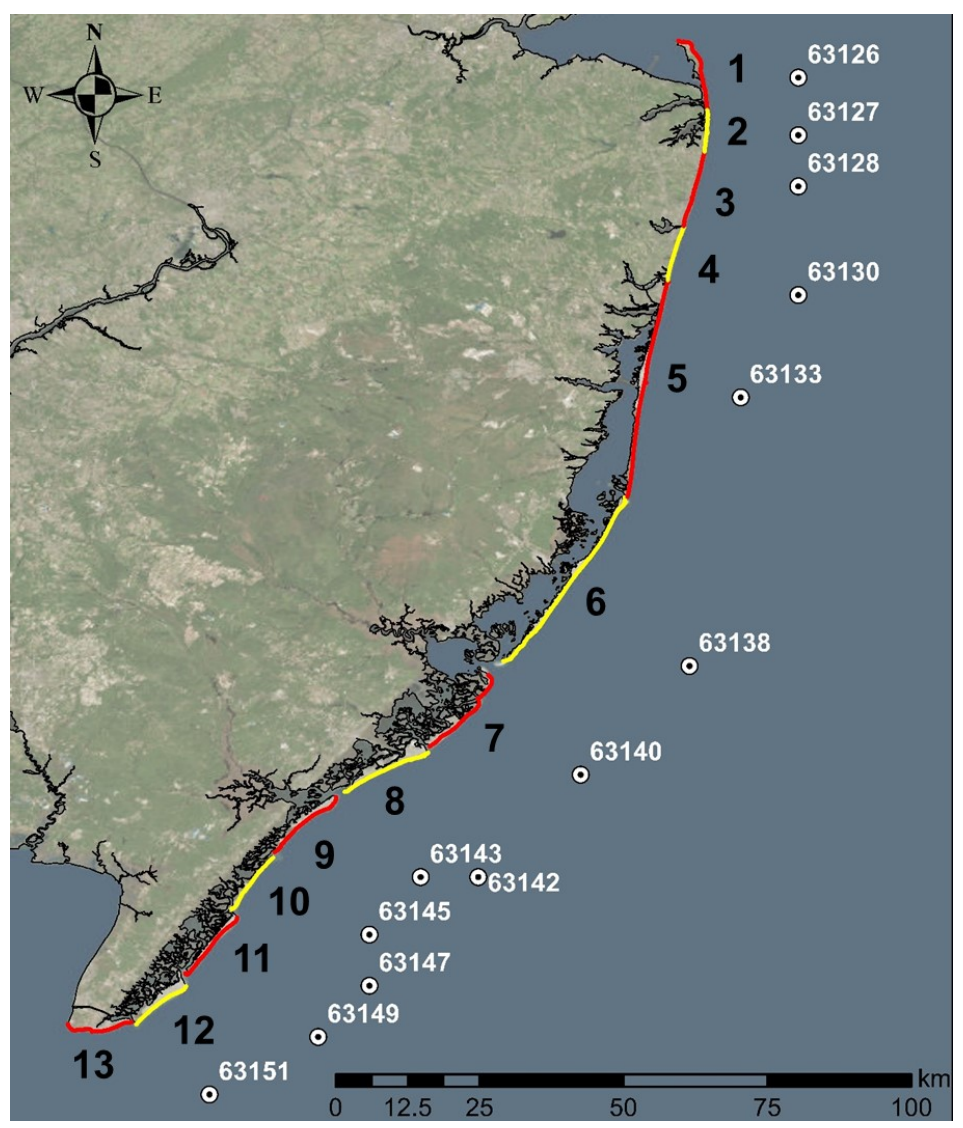

Figure 2. New Jersey shoreline segments for which a storm erosion climatology is developed with nearby WIS virtual buoys shown in white.

Wave and water level information for the past several decades are required to identify historical storms and to calculate the IEI. This information is obtained from available hindcast sources. Offshore directional wave information is obtained from the United States Army Corps of Engineers' (USACE) Wave Information Studies (WIS) Hindcast (USACE 2015). USACE uses a discrete spectral wave model with wind-forcing to generate a spatially and temporally varying wave field for coasts of the US and its territories for the time period of 1980 to 2014. Time series of wave properties are provided at virtual buoys located in approximately $15-20 \mathrm{~m}$ of water approximately every 10 kilometers along the coast. Wave information from the virtual buoy located closest to the center of each shoreline segment is used in the analysis. Each buoy is shown in Figure 2 and listed in Table 1.

A corresponding time series of water levels is extracted from the 35-year (1970-2013) climatology developed by researchers at Stevens Institute of Technology using the New York Harbor Observing and Prediction System's (NYHOPS) hydrodynamic model (Georgas et al. 2016). This model applies surface metrological and hydrologic forcings to reanalyze total water level conditions in the domain covering Massachusetts through Maryland. Water levels are extracted from the grid cell nearest to the coast at the center of each shoreline segment. The combination of the wave height and water level data sets yields a study period of 34 years (1980-2013).

\section{Storm Erosion Index Application}

Prior to the calculation of the IEI the wave record is assessed to ensure the waves considered in the analysis are both erosional and directed onshore. Offshore waves are considered to be those with a wave angle of greater than 90 degrees relative to shore-normal and are removed from the data set. Wave steepness is used to distinguish between waves that are considered to be erosional and those considered accretional. The general rule of thumb has been that waves with a steepness exceeding 0.025 are erosional (Johnson 1949; Waters 1939). However, other laboratory experiments have indicated this 
value may be too conservative and the critical steepness is in fact lower. King and Williams (1949) found the critical steepness to be 0.012 whereas values even smaller have been suggested by others based on large-scale testing and field studies (King 1953; Masselink et al. 2010; Saville 1957). For this study, waves with a steepness value less than 0.012 are considered accretional and are removed from the record. Waves meeting both criteria described above are shoaled and refracted to the breakpoint using linear wave theory. The instantaneous erosion intensity (IEI) is calculated hourly based on the hourly breaking wave heights and water levels remaining in the record.

Individual storms are identified by setting objective criteria. A storm is assumed to exist when either the breaking wave height exceeds the $97 \%$ threshold or the water level exceeds the $99.9 \%$ threshold. Storm duration, $t_{d}$, is defined as the time between when this threshold is first met and when it is no longer met. An example of this is shown in Figure 3. If two instances are separated by less than 48 hours they are considered to be part of the same storm. This accounts for cases where the storm conditions temporarily subside, potentially failing to meet the set criteria, but then pick up again in intensity.

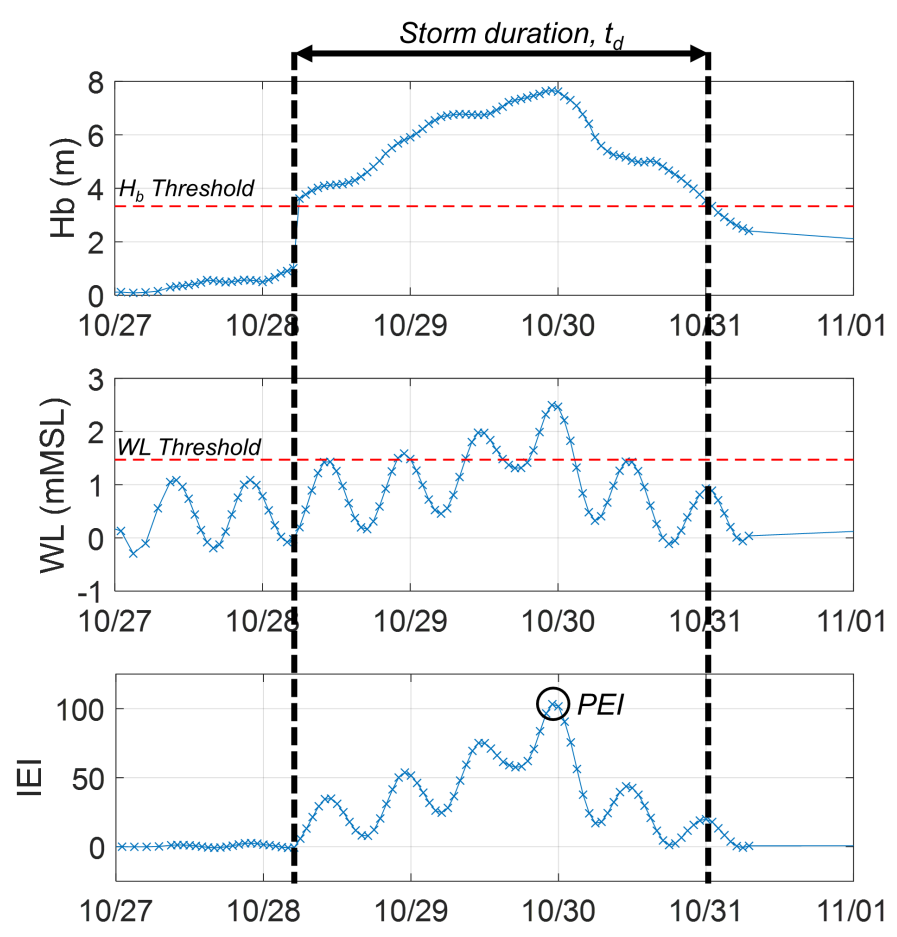

Figure 3. Example of breaking wave height, water level, and calculated IEI during Hurricane Sandy (October 2012) with wave and water level thresholds to define storm duration shown as red dotted lines.

The SEI of an individual storm event is calculated by summing the IEI hourly over the storm duration. This includes all time steps between the start and end point whether or not the individual time steps themselves meet the wave and water level threshold criteria. The PEI is determined for each storm by taking the highest value of the IEI within the storm duration, as depicted in Figure 3. SEI and PEI values are determined for each identified storm in the record. This procedure is performed for each shoreline segment. Storms are then classified in terms of SEI and PEI based on the POT and categorization analyses described above. This results in a ranking of storms for each shoreline segment.

\section{RESULTS}

The Storm Erosion Index was applied here to establish a historical record of storms for each region of New Jersey where storms are ranked based on erosion potential. Doing so creates a record future storms can be compared to. This record contains the SEI, PEI, and associated return periods and categories for each storm identified in the 34-year record though the methods described in the previous sections. Individual records exist for all thirteen shoreline segments. The focus of the results presented in this paper will be a brief analysis of the top several individual storms based on SEI, how their 
impacts in New Jersey varied spatially, and how the different drivers of coastal erosion impact the results for the identified storms.

\section{Identification of Major Storms}

In this paper, the top five storms for four representative shoreline segments are presented (Table 2). Shoreline Segments 3 and 5 are located in the northern half of the state (Figure 1), north of Barnegat Inlet, whereas, the other two, Shoreline Segments 8 and 11, are located in the southern half. The top three storms identified across all shoreline segments are the December 1992 nor'easter, the Veteran's Day Storm (November 2009), and Hurricane Sandy (October 2012); however, their order varies depending on location. All three storms are categorized as Category 5 based on SEI at nearly every shoreline segment, with exceptions for the Veteran's Day Storm at the four northernmost shoreline segments where it is only a Category 4 . All three storms have return periods based on SEI of at least 10 years across all shoreline segments. Because the range of values for SEI and PEI are site specific, when comparing storms across shoreline segments, return periods are used as the basis for comparison.

\begin{tabular}{|c|c|c|c|c|c|c|c|}
\hline \multicolumn{8}{|c|}{ Shoreline Segment 3: Long Branch to Shark River Inlet } \\
\hline Rank & Date & SEI & $\begin{array}{l}\text { SEI Return } \\
\text { Period (yr) }\end{array}$ & $\begin{array}{c}\text { SEI } \\
\text { Category }\end{array}$ & PEI & $\begin{array}{l}\text { PEI Return } \\
\text { Period (yr) }\end{array}$ & $\begin{array}{c}\text { PEI } \\
\text { Category }\end{array}$ \\
\hline 1 & $10 / 2012$ & 2622 & 33 & 5 & 134 & 134 & 5 \\
\hline 2 & 12/1992 & 2566 & 31 & 5 & 86 & 29 & 4 \\
\hline 3 & $11 / 2009$ & 1598 & 13 & 4 & 60 & 7.5 & 3 \\
\hline 4 & $10 / 2005$ & 1592 & 13 & 4 & 46 & 2.4 & 2 \\
\hline 5 & $10 / 2009$ & 1153 & 7.3 & 3 & 37 & 0.9 & 2 \\
\hline \multicolumn{8}{|c|}{ Shoreline Segment 5: Manasquan Inlet to Barnegat Inlet } \\
\hline Rank & Date & SEI & $\begin{array}{l}\text { SEI Return } \\
\text { Period (yr) }\end{array}$ & $\begin{array}{c}\text { SEl } \\
\text { Category }\end{array}$ & PEI & $\begin{array}{l}\text { PEI Return } \\
\text { Period }(\mathrm{yr})\end{array}$ & $\begin{array}{c}\text { PEI } \\
\text { Category }\end{array}$ \\
\hline 1 & $10 / 2012$ & 2653 & 35 & 5 & 102 & 140 & 5 \\
\hline 2 & $12 / 1992$ & 2580 & 32 & 5 & 81 & 30 & 4 \\
\hline 3 & $11 / 2009$ & 2361 & 24 & 5 & 65 & 8.9 & 4 \\
\hline 4 & $10 / 2005$ & 1722 & 9.9 & 4 & 48 & 2.1 & 3 \\
\hline 5 & $09 / 2008$ & 1510 & 7.1 & 3 & 47 & 1.9 & 3 \\
\hline \multicolumn{8}{|c|}{ Shoreline Segment 8: Absecon Inlet to Great Egg Harbor Inlet } \\
\hline Rank & Date & SEI & $\begin{array}{l}\text { SEI Return } \\
\text { Period (yr) }\end{array}$ & $\begin{array}{c}\text { SEl } \\
\text { Category }\end{array}$ & PEI & $\begin{array}{l}\text { PEI Return } \\
\text { Period (yr) }\end{array}$ & $\begin{array}{c}\text { PEI } \\
\text { Category }\end{array}$ \\
\hline 1 & $11 / 2009$ & 4187 & 41 & 5 & 93 & 8.2 & 4 \\
\hline 2 & $10 / 2012$ & 3922 & 33 & 5 & 130 & 135 & 5 \\
\hline 3 & $12 / 1992$ & 3776 & 29 & 5 & 108 & 24 & 5 \\
\hline 4 & $09 / 2008$ & 2814 & 11 & 4 & 74 & 2.4 & 3 \\
\hline 5 & $10 / 1984$ & 2568 & 8.7 & 4 & 82 & 3.8 & 4 \\
\hline \multicolumn{8}{|c|}{ Shoreline Segment 11: Townsends Inlet to Hereford Inlet } \\
\hline Rank & Date & SEI & $\begin{array}{l}\text { SEI Return } \\
\text { Period (yr) }\end{array}$ & $\begin{array}{c}\text { SEI } \\
\text { Category }\end{array}$ & PEI & $\begin{array}{l}\text { PEI Return } \\
\text { Period (yr) }\end{array}$ & $\begin{array}{c}\text { PEI } \\
\text { Category }\end{array}$ \\
\hline 1 & $12 / 1992$ & 5119 & 36 & 5 & 135 & 22 & 5 \\
\hline 2 & $11 / 2009$ & 5034 & 33 & 5 & 121 & 8.7 & 5 \\
\hline 3 & $10 / 2012$ & 4790 & 27 & 5 & 154 & 99 & 5 \\
\hline 4 & $10 / 1991$ & 3568 & 9.8 & 4 & 121 & 8.4 & 5 \\
\hline 5 & $09 / 2008$ & 3320 & 7.9 & 4 & 95 & 2.0 & 4 \\
\hline
\end{tabular}

Each of the top three identified storms are known to have resulted in major erosion of the New Jersey coast. As the December 1992 nor'easter moved up the east coast it experienced a rapid drop of its central pressure, producing a strong pressure gradient and high winds (NOAA 1992). Sustained wind speeds were 15 to $20 \mathrm{~m} / \mathrm{s}$ with gusts at times reaching hurricane force. These winds produced significant waves and in combination with elevated water levels, the storm resulted in considerable beach and dune erosion throughout New Jersey. At the time, coastal flooding due to the storm was the worst it had been in forty years. Damage to seawalls, piers, homes, and other structures was sustained. It was estimated that damage to the beaches and other property was over $\$ 100$ million.

The Veteran's Day Storm in November 2009 formed from the remnants of Hurricane Ida as it collided with another low pressure system developing off the coast of North Carolina. Rather than being notable for high wind speeds or storm surge, it is most notable for its long duration, lasting about four days. Damage sustained in Ocean, Atlantic, and Cape May counties prompted a Presidential Disaster 
Declaration. Due to the nature of the storm, the southern portions of New Jersey fared worse than those in the north, particularly areas such as Atlantic City, Ocean City, and Avalon which are located within Shoreline Segments 8, 10, and 11 respectively (Farrell et al. 2010).

Hurricane Sandy which impacted New Jersey in October 2012 is to date the costliest natural disaster in the state resulting in nearly $\$ 30$ billion worth of damages including but not limited to the damage of 346,000 housing units with 22,000 of those uninhabitable (Blake et al. 2013; NJOEM 2014). The storm, which was a late-season hurricane, made landfall in Brigantine, New Jersey as a posttropical cyclone. As a reference, Brigantine is located about the midway point of Shoreline Segment 7 identified for this study (Figure 1, Table 1). Sustained wind speeds were approximately $25 \mathrm{~m} / \mathrm{s}$ and waves measured a maximum of $9.6 \mathrm{~m}$ at the offshore NDBC buoy 44025 located approximately 70 kilometers off the coast of northern New Jersey. Combined with a record-breaking storm surge, measuring $2.6 \mathrm{~m}$ at the Sandy Hook NOAA tide station, the storm resulted in massive damage to the coastline. Both beaches north and south of its landfall were impacted. In general, beaches towards the south were impacted less severely than those to the north due to the shift in wind direction as the storm made landfall (Barone et al. 2014).

For the shoreline segments located in the northern half of New Jersey, Hurricane Sandy is close to if not the top-ranked storm based on SEI. For the more southern segments, Sandy falls in rank at times behind both the Veteran's Day storm and the December 1992 nor'easter as in the case of Shoreline Segment 11 (Table 2). This fall in rank is also associated with a general decrease in return period as it decreases from a maximum of 38 years at Shoreline Segment 4 to a minimum of 23 years at Shoreline Segment 10 as shown in Figure 3. This general decrease in return period of Hurricane Sandy based on SEI corresponds well with general observations that the storm appeared to cause more coastal erosion in northern New Jersey than it did in the south (Barone et al. 2014).

While Hurricane Sandy and the December 1992 nor'easter tend to have higher return periods in the north, the Veteran's Day Storm has higher return periods in the south. A maximum return period based on SEI of 42 years occurs at Shoreline Segment 9, whereas the minimum of about 13 years occurs at Shoreline Segment 3 (Figure 3). This is supported by general observations that the Veteran's Day Storm impacted southern New Jersey more severely than it did the northern portion of the state (Farrell et al. 2010). A split in these general trends appears to occur at Shoreline Segment 6. Shoreline Segment 6 is also where the shoreline orientation of New Jersey's coastline shifts which suggests that shoreline orientation relative to the storm waves may be an important factor in determining erosion potential.

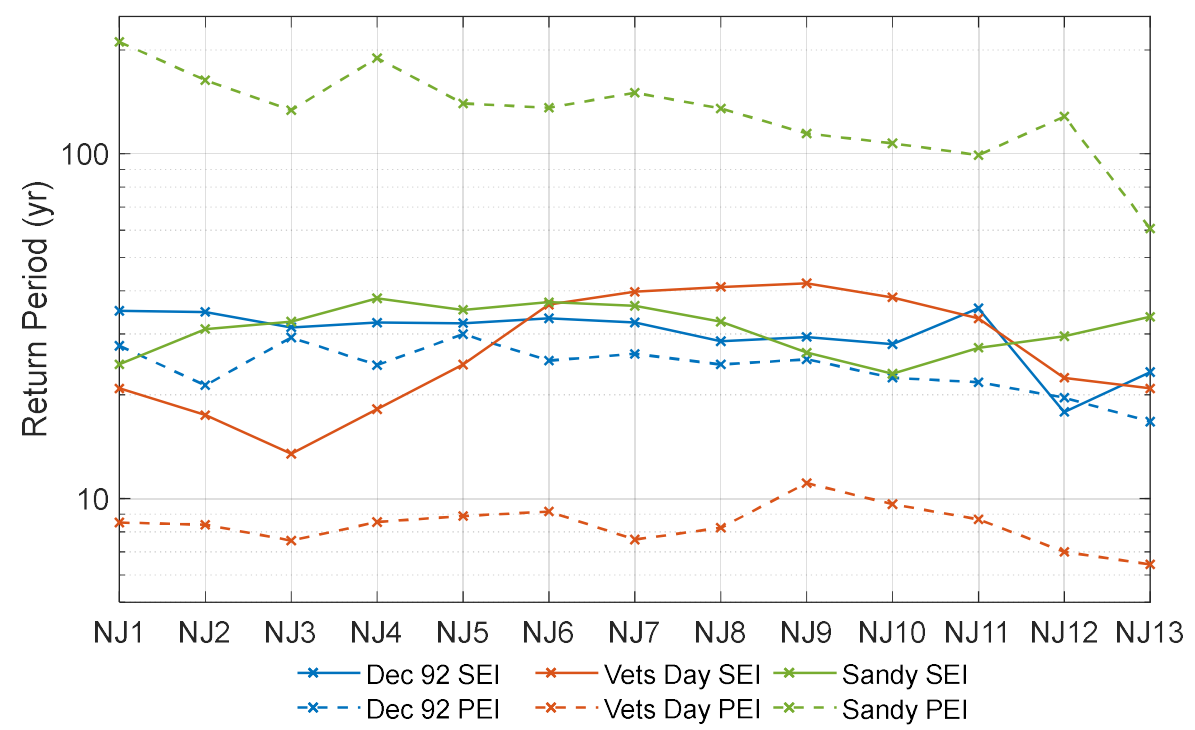

Figure 3. Return periods based on SEI (solid lines) and PEI (dotted lines) for the top three coastal storms in New Jersey including the December 1992 nor'easter (blue), the Veteran's Day Storm in November 2009 (orange), and Hurricane Sandy in October 2012 (green).

Based on PEI or the peak erosion intensity, Hurricane Sandy is ranked first across all shoreline segments. Of the three storms discussed thus far, the December 1992 nor'easter is second followed by the Veteran's Day Storm. However, it should be noted that other storms including "The Perfect Storm" 
in October 1991 and Hurricane Irene in August 2011 exceed the Veteran's Day Storm in terms of PEI at several shoreline segments. Although Hurricane Sandy remains the highest ranked storm based on PEI across all shoreline segments, the intensity decreases relative to the other storms. The return periods based on PEI decreases from well over 100 years at Shoreline Segment 1 (Sandy Hook) to around 60 years at Shoreline Segment 13 (Cape May) (Figure 3). Return periods based on PEI for the December 1992 nor'easter are between 20 and 30 years whereas as that for the Veteran's Day Storm are between 7 and 10 years.

\section{Role of Shoreline Erosion Drivers in PEI and SEI}

PEI reflects the maximum instantaneous erosion intensity during the storm and is commonly influenced by the maximum breaking wave height, maximum water level, and the timing of the two with relation to one another. An example time series of breaking wave height and water level for the top three storms is shown in Figure 4 for Shoreline Segment 8. The maximum breaking wave height and maximum water level for Hurricane Sandy exceed that of the other two storms. Additionally, they appear to occur simultaneously leading to Hurricane Sandy having the highest PEI. One contribution to the decrease in the return period of Hurricane Sandy based on PEI from northern to southern New Jersey is a decrease in maximum breaking wave height and total water level during the storm from one location to the other.

Of the three storms, the December 1992 nor'easter has the next highest PEI which is a result of its large maximum breaking wave height and water level, though neither as large as that for Hurricane Sandy. The Veteran's Day Storm, though having a higher maximum breaking wave height that the December 1992 nor'easter has lower water levels and the combination of the two lead to a smaller PEI.

While PEI reflects the maximum instantaneous erosion intensity, SEI also considers storm duration and reflects the summation of the instantaneous intensity over that duration. The storm duration defines the length of time storm conditions act on the beach and cause erosion. Even if a storm is intense with elevated water levels and increased wave heights, if it moves quickly, it does not have as much time to act on the beach and accumulate effects. The examples of Hurricane Sandy and the Veteran's Day Storm in particular help illustrate the importance of storm duration when considering the erosion potential of a storm. Although Hurricane Sandy exceeds all other storms at every shoreline segment in terms of PEI, which is a response to its instantaneously high water levels and wave heights, it does not always rank first in terms of SEI, which is a response to its intensity over storm duration.

An example of this is at Shoreline Segment 8 where the Veteran's Day Storm has a lower PEI than both Hurricane Sandy and the December 1992 nor'easter yet ranks above each it terms of SEI. Time series of breaking wave height, water level, and IEI for each storm are depicted in Figure 4. It should be noted that breaking wave height is only shown for those waves which meet the criteria described in the earlier section and is shown as 0 at all other timesteps. As discussed, Hurricane Sandy's maximum breaking wave height and maximum water level of $7.0 \mathrm{~m}$ and $2.04 \mathrm{mMSL}$ exceed those of the other two storms (Table 3). These two occur nearly simultaneously leading to Hurricane Sandy having the highest PEI of any of the storms in the record with a value of 130 and a return period of over 100 years.

However, in terms of cumulative erosion potential, represented by SEI, Hurricane Sandy is lower than the Veteran's Day Storm at this shoreline segment despite this higher peak intensity. This can be attributed to the storm duration. The Veteran's Day Storm's duration based on the thresholds set in this analysis is 89 hours, more than a day longer than Hurricane Sandy with a duration of 60 hours. Of the top three storms the Veteran's Day Storm has the longest duration and in combination with its large wave heights and fairly high water levels it is the storm with the highest erosion potential despite having a lower maximum water level and PEI.

\begin{tabular}{|c|c|c|c|c|c|c|}
\hline \multicolumn{7}{|c|}{ Shoreline Segment 8: Absecon Inlet to Great Egg Harbor Inlet } \\
\hline Rank & Date & SEI & PEI & $\begin{array}{l}\operatorname{Max}_{\mathrm{H}_{\mathrm{b}}} \\
(\mathrm{m})\end{array}$ & $\begin{array}{l}\text { Max WL } \\
\text { (mMSL) }\end{array}$ & $\begin{array}{c}\text { Duration } \\
\text { (hr) }\end{array}$ \\
\hline 1 & $11 / 2009$ & 4187 & 93 & 6.5 & 1.55 & 89 \\
\hline 2 & $10 / 2012$ & 3922 & 130 & 7.0 & 2.04 & 60 \\
\hline 3 & 12/1992 & 3776 & 108 & 6.4 & 1.81 & 82 \\
\hline 4 & 09.2008 & 2814 & 74 & 6.1 & 1.30 & 101 \\
\hline 5 & $10 / 1984$ & 2568 & 82 & 6.4 & 1.35 & 67 \\
\hline
\end{tabular}



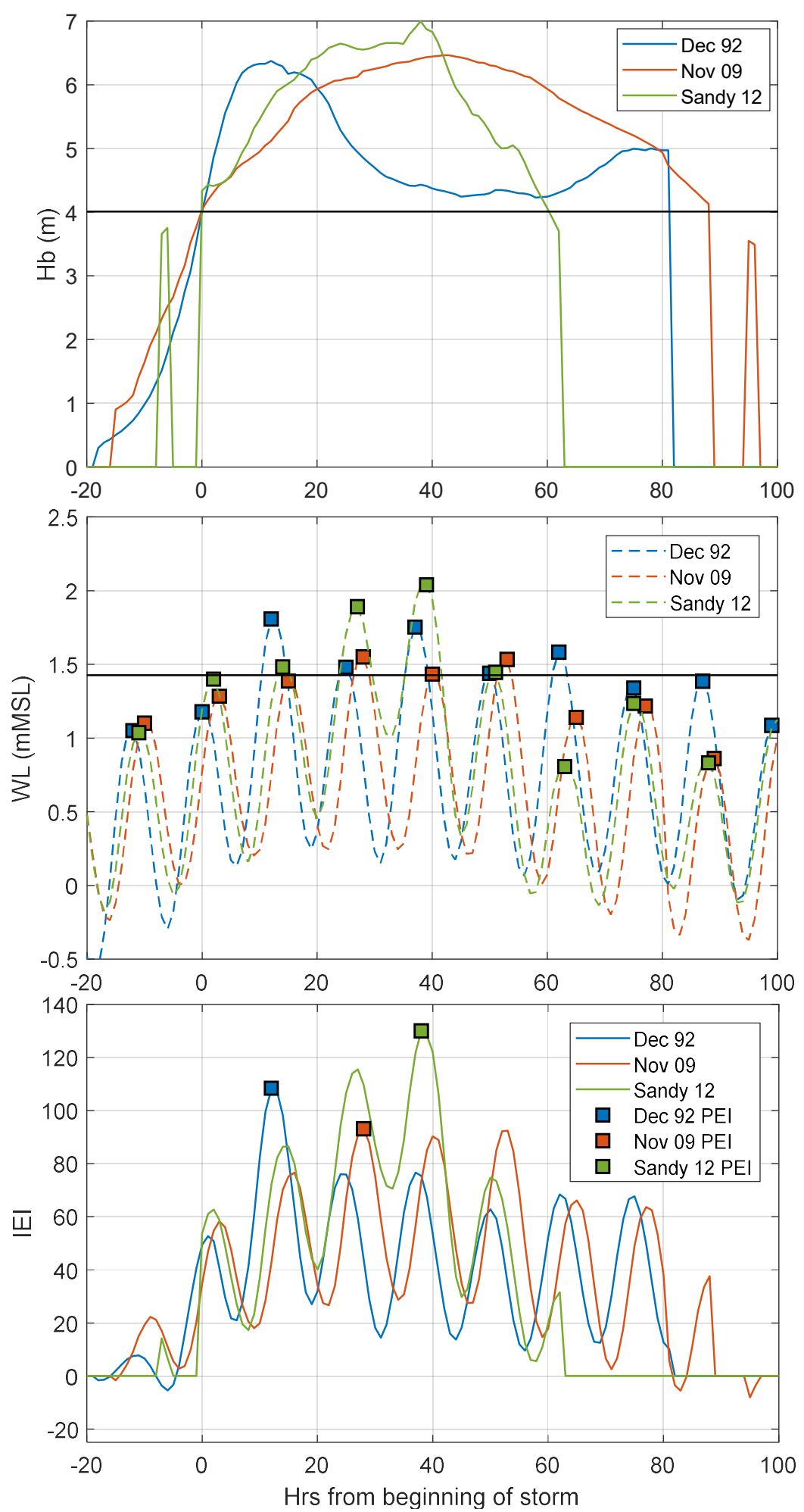

Figure 4. Breaking wave height (top), total water level (middle), and IEI (bottom) at Shoreline Segment 8 for three major coastal storms events in New Jersey including the December 1992 nor'easter, the Veteran's Day Storm (November 2009), and Hurricane Sandy (October 2012). Wave and water level thresholds to determine storm duration are depicted as black horizontal lines. Water levels at high tide highlighted with squares. 


\section{DISCUSSION}

\section{Advantages of Storm Erosion Index}

The analysis presented in this paper illustrates the strengths of the Storm Erosion Index. Here, a 34year period is analyzed to identify on average 135 storms at each shoreline segment. At each shoreline segment these storms are ranked based on their erosion potential, or SEI, calculated using the equations presented above. One advantage of this method over others is that all storms are analyzed via the same method whether they are tropical or extratropical storms. As discussed earlier, many ways by which storm intensity is assessed were developed with a focus on either tropical or extratropical storms. New Jersey is impacted by both types and it is valuable to be able to compare the two using the same criteria. Based on SEI, the top three storms across all shoreline segments in New Jersey are the December 1992 nor'easter, the Veteran's Day Storm in November 2009, and Hurricane Sandy in October 2012. Spatial differences between the two storms are identified based on changes in return period between the northern and southern portions of the state. While Hurricane Sandy and the December 1992 nor'easter tend to have higher return periods in the north, the Veteran's Day Storm has higher return periods in the south.

Another advantage of this method is the inclusion of all three drivers of coastal erosion in the analysis, particularly storm duration, which is often overlooked. The importance of this parameter is reflected by the Veteran's Day Storm in November 2009, which is a well-known coastal event in New Jersey, that resulted in significant erosion particularly in southern New Jersey. At Shoreline Segment 8, using more typical means of classifying storm intensity such as by wave height or water level, this storm would not be ranked first as it is by SEI with a return period of 41 years. Based on either maximum breaking wave height or water level, the storm would be ranked as sixth and have a return period on the order of 5 years. Erosion potential for this storm would be underestimated if the prediction was based on either of these parameters alone.

In contrast, other storms which peak very quickly but only impact the coast on the order of a few hours would be overestimated. An example of this at the discussed shoreline segment is Hurricane Earl which occurred in September 2010 and has a return period of about 1 year based on SEI and is classified as Category 1. However, maximum breaking wave heights are the 5th largest on record. The storm however was quick-moving with a duration of 12 hours and impacts were ordinary. To confirm, NJDEP post-storm reports recorded no significant impacts in most of the region with only some spots reporting isolated erosion.

\section{Applications}

The work presented in this paper creates the foundation for future applications. The historical records established for each of the thirteen shoreline segments provide a baseline to compare future storms in the state to. One application of this product is the prediction of erosion potential for approaching storms. For this, SEI is calculated using the same procedures discussed in this paper based on forecasts of waves and water levels at each shoreline segment. Values are compared to the historical records presented here to estimate return period and category.

At this point, it is important to acknowledge that SEI is an indication of the storm's erosion potential based primarily on the characteristics of the storm itself, exclusive of many of the characteristics of the beach. The true performance of the beach and dune system may not necessarily be predicted on the erosion potential alone but must also consider the current state of the beach. Locations close to one another but with different levels of protection may experience very different impacts. This is evident by the impacts seen to two sites in New Jersey during Hurricane Sandy, Seaside Park and Ortley Beach. The two towns are both located on Barnegat Island, which is identified as Shoreline Segment 5 in this study, and are just $4 \mathrm{~km}$ apart. As shown in Figure 5, as a result of Hurricane Sandy, the dune was completely removed in Ortley Beach leaving properties located behind the system exposed to damage. However, that of Seaside Park was eroded but was left intact with the dune crest remaining at the same elevation, providing continuous protection to the landward properties (The Stockton University Coastal Research Center 2012). In close proximity to one another it can be assumed that the storm conditions were similar and that differences in performance are due to the state of the beach and dune system itself. Prior to Hurricane Sandy Seaside Park had a much larger dune with a crest elevation of nearly 8 mNAVD 88 and a volume of approximately 90 cubic meters per meter in the frontal dune section above the 100 year stillwater level. This exceeds the 540 cubic feet per foot (50 cubic meters per meter), which is the threshold recommended by Hallermeier and Rhodes (1986) and Dewberry \& Davis (1989) to withstand an erosional event. This recommendation is commonly referred 
to as FEMA 540 rule (FEMA 2011). The dune at Ortley Beach had a much smaller volume of approximately 12 cubic meters per meter in the frontal dune and a crest elevation of just over 5 mNAVD88. Based on this example, it is important for emergency planners to understand both the erosion potential of the storm as well as the state of their beach prior to storm impact.

The climatology developed here provides a baseline for comparison for an oncoming storm's erosion potential. However, emergency planners must consider the state of the beach at the time storms of similar magnitude occurred, how it had fared, and how the current state of the beach compares to that. Future work will look at combining the Storm Erosion Index and beach characteristics to predict beach performance during a storm.
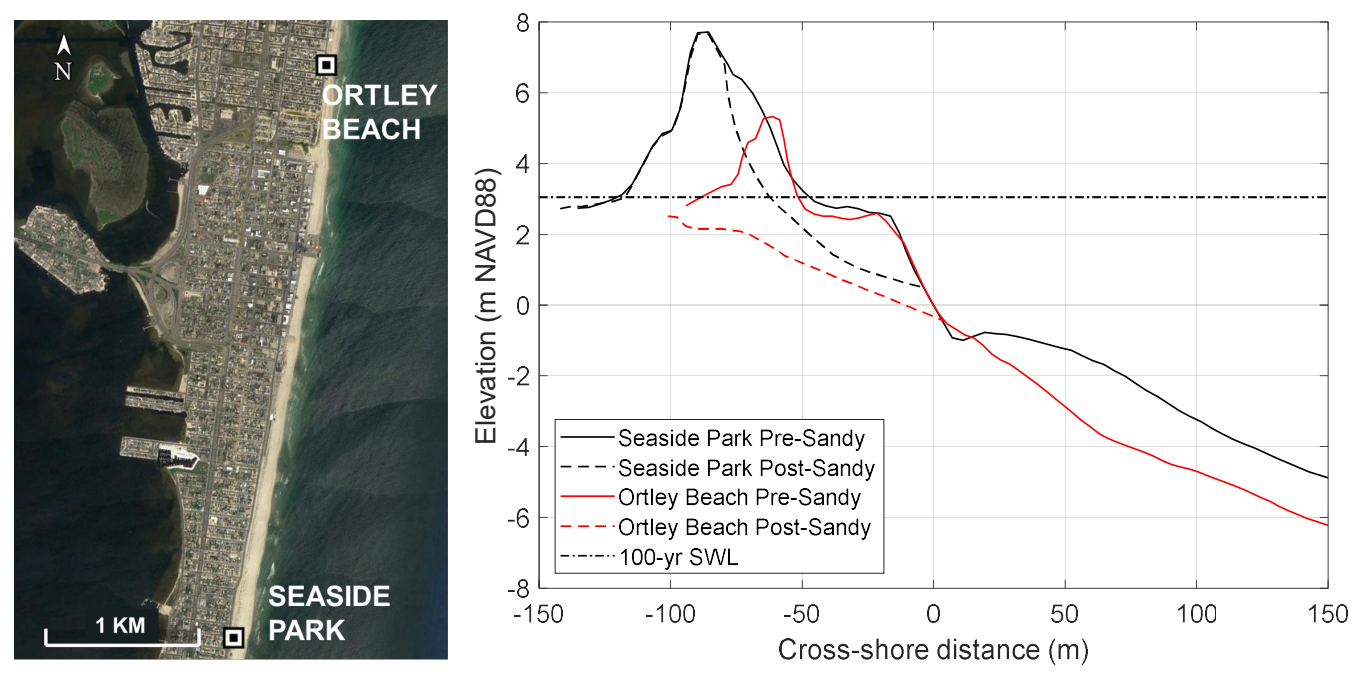

Figure 5. (Left) Map indicating locations of Ortley Beach and Seaside Park, New Jersey. (Right) Pre- and post- Hurricane Sandy profiles at Ortley Beach and Seaside Park, both of which are located in Shoreline Segment 5. Reproduced from The Stockton University Coastal Research Center (2012).

\section{ACKNOWLEDGMENTS}

The authors wish to acknowledge Virginia Sea Grant and the NOAA Coastal Storms Program for both their time as well as for their financial support of the project. The continued support of the New Jersey Department of Environmental Protection in furthering the development of the SEI through the New Jersey Coastal Protection Technical Service Assistance Service (N.J.S.A 18A:64L-1) is also gratefully acknowledged.

\section{REFERENCES}

Barone, D., McKenna, K. and Farrell, S. 2014. Hurricane Sandy: Beach-dune performance at New Jersey Beach Profile Network sites, Shore \& Beach, 82, 13-23.

Blake, E.S., Kimberlain, T.B., Berg, R.J., Cangialosi, J.P. and Beven, J.L. 2013. Tropical cyclone report: Hurricane Sandy, National Hurricane Center.

Bruun, P. 1962. Sea-level rise as a cause of shore erosion, Journal of Waterway Port Coastal and Ocean Engineering, 88(1), 117-132.

Dean, R.G. and Dalrymple, R.A. 2002. Coastal Processes with Engineering Applications, Cambridge University Press, New York, NY, 475 pp.

Dean, R.G., Walton, T.L. and Kriebel, D.L. 2001. Cross-shore sediment transport. Coastal Engineering Manual, US Army Coastal \& Hydarulics Laboratory.

Dewberry \& Davis, I. 1989. Basis of assessment procedures for dune erosion in coastal flood insurance studies.

Dolan, R. and Davis, R.E. 1992. An intensity scale for Atlantic coast northeast storms, Journal of Coastal Research, 8(4), 840-853.

Done, J.M., PaiMazumder, D., Towler, E. and Kishtawal, C.M. 2015. Estimating impacts of North Atlantic tropical cyclones using an index of damage potential, Climatic Change, 146(3-4), 561573. 
Farrell, S.C. et al. 2010. New Jersey Beach Profile Network 2009 annual report on shoreline changes in New Jersey coastal reaches one through fifteen Raritan Bay to Delaware Bay, The Richard Stockton Coastal Research Center.

Farrell, S.C. et al. 2016. New Jersey Beach Profile Network 2015 annual report on shoreline changes in the four coastal counties Raritan Bay to Delaware Bay, The Richard Stockton Coastal Research Center.

FEMA. 2011. Coastal construction manual, 1, Federal Emergency Management Agency, 253 pp.

Flynn, M.J. Sediment characterization of the New Jersey shoreline: Comparison of median grain size distribution from 1950 to 2011, The Richard Stocton College Coastal Research Center.

Georgas, N. et al. 2016. An open-access, multi-decadal, three-dimensional, hydrodynamic hindcast dataset for the Long Island Sound and New York/New Jersey Harbor estuaries, Journal of Marine Science and Engineering, 4(3).

Hallermeier, R.J. and Rhodes, P.E. 1986. Description and assessment of coastal dune erosion, Dewberry \& Davis, Inc.

Hebert, C.G., Weinzapfel, R.A. and Chambers, M.A. 2010. Hurricane Severity Index: A new way of estimating a tropical cyclones destructive potential. 29th Conference on Hurricanes and Tropical Meteorology.

Herrington, T.O. and Miller, J.K. 2010. A comparison of methods used to calculate northeaster damage potential, Shore \& Beach, 78(2), 20-25.

Johnson, J.W. 1949. Scale effects in hydarulic models involving wave motion, Transactions of the American Geophysical Union, 30(4), 517-525.

Kantha, L. 2006. Time to replace the Saffir- Simpson Hurricane Scale?, Eos, Transactions American Geophysical Union, 87(1), 3-6.

King, C.A.M. 1953. The relationship between wave incidence, wind direction, and beach changes at Marsden Bay, County Durham, Transactions and Papers (Institute of British Geographers), 19, 13-23.

King, C.A.M. and Williams, W.W. 1949. The formation and movement of sand bars by wave action, The Geographical Journal, 113, 70-85.

Kriebel, D., Dalrymple, R., Pratt, A. and Sakovich, V. 1996. Shoreline risk index for northeasters. Proceedings of the 1996 Conference on Natural Disaster Reduction, 251-252.

Lang, M., Ouarda, T.B.M.J. and Bobee, B. 1999. Towards operational guidelines for over-threshold modeling, Journal of Hydrology, 225(3-4), 103-117.

Masselink, G., Russell, P., Blenkinsopp, C. and Turner, I. 2010. Swash zone sediment transport, step dynamics and morphological response on a gravel beach, Marine Geology, 274(1-4), 50-68.

Mendoza, E.T., Jimenez, J.A. and Mateo, J. 2011. A coastal storms intensity scale for the Catalan sea (NW Mediterranean), Natural Hazards and Earth System Sciences, 11(9), 2453-2462.

Miller, J.K. 2015. Evaluation of storm severity based on the Storm Erosion Index along the Atlantic Coasts of North Carolina and South Carolina. Technical report prepared for the Charleston District of the USACE., Stevens Insitute of Technology, Davidson Laboratory.

Miller, J.K. and Dean, R.G. 2004. A simple new shoreline change model, Coastal Engineering, 51(7), 531-556.

Miller, J.K. and Livermont, E. 2008. A predictive index for wave and storm surge induced erosion. Proceedings of the 31st International Conference on Coastal Engineering, Hamburg, Germany, 4143-4153.

Miller, J.K. and Wehof, J. 2013. Evaluation of storm severity based on the Storm Erosion Index along the Southeast Atlantic Coast of Florida in the wake of Hurricane Sandy. Technical report prepared for the Jacksonville District of the USACE., Stevens Insitute of Technology, Davidson Laboratory.

Moore, B.D., 1982. Beach profile evolution in response to changes in water level and wave height. MCE Thesis, Department of Civil Engineering, University of Delaware, 164 pp.

NJOEM. 2014. 2014 New Jersey State hazard mitigation plan.

NOAA. 1992. Storm data with annual summaries and unusual weather phenomena with late reports and corrections. Volume 34. No. 12., National Oceanic and Atmospheric Administration.

Palutikof, J.P., Brabson, B.B., Lister, D.H. and Adcock, S.T. 1999. A review of methods to calculate extreme wind speeds, Meteorological Applications, 6(2), 119-132.

Saville, T. 1957. Scale effects in two dimensional beach studies. Transactions from the 7th General Meeting of the International Association of Hydraulic Research, A3-1-A3-10.

Schott, T. et al. 2012. The Saffir-Simpson Hurricane Wind Scale, NOAA/Naitional Weather Service. 
The Stockton University Coastal Research Center. 2012. Beach dune performance assessment of New Jersey Beach Profile Network (NJBPN) sites at Northern Ocean County, New Jersey, after Hurricane Sandy related to FEMA disaster DR-NJ-4086.

USACE. 2015. Wave Infomation Studies. Retrieved from http://wis.usace.army.mil/.

Waters, C.H., 1939. Equilibrium slopes of sea beaches, University of California, Berkeley, CA.

Wehof, J., Miller, J.K. and Engle, J. 2014. Application of the Storm Erosion Index (SEI) to three unique storms. Proceedings of the 34th International Conference on Coastal Engineering, Seoul, Korea. 